lower band, and the coal directly below it, are exposed in an adit in Acton Cleugh.

A nearby N.C.B. borehole at NY 9758654600 proved black siltstone between $102 \mathrm{ft} .8 \mathrm{in}$. and $103 \mathrm{ft} .9 \mathrm{in}$.; Lingula mytilloides J. Sowerby at the base of this bed represents the Upper Acton Cleugh Marine Band. The bulk of the siltstone yielded Rhadinichthys scales, Palaeoniscid scales, and (towards the top) Anthraconaia sp.

This Anthraconaia appears to be an undescribed form belonging to the A. modiolaris group. According to Mr. M. A. Calver and Dr. J. Weir (in litt) it is likely to be from the Westphalian rather than the Namurian. Similar forms have been recorded near the lenisulcata-communis boundary in South Wales (Calver in Woodland, Archer and Evans, 1957, p. 56) and in the Pennines (Calver, 1955, Fig. 4). In view of the presence of marine bands higher in the sequence (Text-fig. 1) it must be supposed that the horizon of the present occurrence is within the lenisulcata Zone.

This find implies that much (here, at least 200 feet) of the " Millstone Grit" must be assigned to the Westphalian. Existing records of this form of Anthraconaia are all at horizons above the G. listeri Marine Band. Probable correlatives of the Lower Acton Cleugh Marine Band, however, at no great distance from the present locality, yield Dunbarella and productids, and this may mean that this Marine Band should be referred to a horizon not higher than one of the basal marine bands of the Westphalian. Productids are not so far known above the G. subcrenatum Marine Band (Calver in Owens and Burgess, 1965 , p. 26). Thus the Namurian-Westphalian junction may be not far below the present occurrence, and might perhaps reasonably be drawn at, or shortly below, the base of the Lower Acton Cleugh Marine Band.

Acknowledgements are due to the National Coal Board, Opencast Executive, for making cores available to inspection.

1a Tranquility Avenue,

C. G. Godwin.

Crossgates,

LEEDS 15.

23rd May, 1966.

\title{
REFERENCES
}

Armstrong, G., and Price, R. H., 1957. The Coal Measures of north-east Durham. Trans. Instn Min. Engrs, 113, 973-997.

Calver, M. A., 1955. Die stratigraphische Verbreitung der Nicht-marinen Muscheln in den penninischen Kohlenfeldern Englands. $Z$. $d t$. geol. Ges., 107, 26-39.

Magraw, D., Clarke, A. M., and Smrth, D. B., 1963. The Stratigraphy and Structure of part of the south-east Durham Coalfield. Proc. Yorks. geol. Soc., 34, 153-208.

Owens, B., and Burgess, I. C., 1965. The Stratigraphy and Palynology of the Upper Carboniferous outlier of Stainmore, Westmoreland. Bull. geol. Surv. Gt Br., 23, 17-44.

Woodland, A. W., Archer, A. A., and Evans, W. B., 1957. Recent boreholes into the Lower Coal Measures beneath the Gellideg-Lower Pumpquart Coal horizon in South Wales. ibid., 13, 39-60.

\section{AN UNCONFORMITY IN THE TORRIDONIAN}

SIR,-In a recent paper by Harland et al. (Geol. Mag., 103, 70-97), the Torridonian was supposed to form an unbroken stratigraphic sequence unconformably overlying the Lewisian basement complex and unconformably overlain by the Cambro-Ordovician (op. cit., Table 3). This, the orthodox view, needs substantial modification.

In 1957 Irving and Runcorn showed that the palaeomagnetic pole directions from the Torridonian between Stoer and Applecross formed two distinct clusters. The field measured at eighty-one sites in the upper part of the 
Torridonian indicated an apparent pole about 70 degrees back along the polar wandering path from the Cambrian position. The pole deduced from the field at thirteen sites in the lower part of the Torridonian, however, lay about 50 degrees farther back still. These apparent pole movements compare with about 100 degrees for the whole of the Phanerozoic. Although the position of the palaeomagnetic field change was thought by Irving and Runcorn (1957, p. 87) to lie within a hundred metre stratigraphic interval at Achiltibuie it did not appear to correspond either here or elsewhere to any of the established Torridonian formation boundaries. Nevertheless, Creer (1957, pp. 126-7) and Creer, Irving and Runcorn $(1957$, p. 146) designated the strata above and below the level of the palaeomagnetic break "Upper" and "Lower" Torridonian, respectively (a nomenclature frequently used by other authors in a different way). The implication was that these were significant timestratigraphic units. They will be used in this sense in the sequel. Creer, Irving and Runcorn $(1957$, p. 149$)$ and Irving $(1964$, p. 276$)$ interpreted the break (supposing it to occur within a continuous sedimentary sequence) as arising from a very rapid polar movement. Runcorn $(1964$, p. 690), however, has proposed the alternative explanation that the Lower Torridonian is simply much older than the Upper.

Taking the palaeomagnetic data at face value a time break of about 280 m.y. might be expected between the Upper and Lower Torridonian, assuming the rate of apparent palaeomagnetic polar migration to have been 0.17 deg. per m.y. (the average for the Phanerozoic). No slower rate can be considered because it would make the Lower Torridonian older than the basement on which it rests. On the other hand, if the maximum known rate of migration during the Phanerozoic is used in the calculation (about $1 \mathrm{deg}$. per m.y. during the Carboniferous in Australia; Irving, 1964, Fig. 6.11 and p. 330) the hiatus is reduced to about $50 \mathrm{~m}$.y. Using the same two migration rates, the time equivalents of the palaeomagnetic break between the Upper Torridonian and the Cambrian work out at respectively 400 m.y. and 70 m.y. Since the palaeomagnetic field only changes markedly between the Upper and Lower Torridonian, not within them, the presently exposed Torridonian sediments must have been deposited " instantaneously " relative to the movement of the palaeomagnetic poles. This agrees with the sedimentological evidence which indicates rapid deposition.

Assumptions involved in the above discussion are : (1) that the rate of apparent polar migration during the Precambrian was constant and did not exceed rates known from the Phanerozoic ; $(2)$ the earth's field during the late Precambrian corresponded to that of a geocentric dipole ; (3) the palaeomagnetic field in the Upper Torridonian strata was established at time of deposition or shortly after. It is known to pre-date the (Precambrian) regional warping of the Upper Torridonian. Any or all of these assumptions could, of course, be wrong.

Recent work at Reading shows that there is a previously unrecognized stratigraphic break within the Torridonian. Lawson (1965, pp. 706-8) has described an erosion surface in the Torridonian at Rudha Reidh and near Stattic Point which he correlates with a similar surface at Enard Bay, earlier discovered by Dr. A. J. Gracie, and with another at Stoer found by Williams $(1966$, p. 1,304). The discontinuous outcrops of this erosion surface and the underlying strata have been mapped by the writer from near Rudha Reidh northward as far as Enard Bay and everywhere they correspond to an angular unconformity of 25-30 degrees (Text-fig. 1). At Stoer, however, the angle is only about 10 degrees. The best localities for demonstrating the angular nature of the unconformity are $5 \mathrm{~km}$. south-east of Rudha Reidh (NG 778886 ), on the coast $2 \mathrm{~km}$. south of Achiltibuie (NC 025067), and on the south side of Enard Bay (NC 031146). Details of the key Enard Bay area will be published shortly (Gracie and Stewart). Generally, strata above the unconformity correlate with the Torridonian of the Torridon-Applecross area. The strata beneath are older. The best section of these older strata is on the peninsula of Stoer, east of the Coigach fault. The sampling sites which 


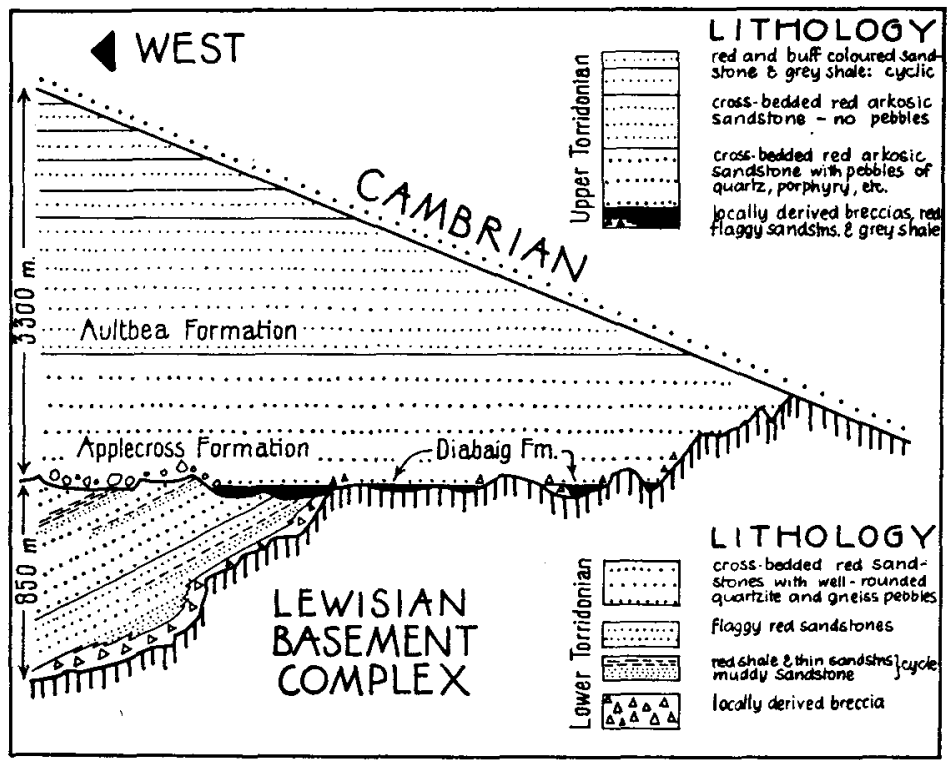

TeXT-FIG. 1.-Schematic cross-section through the Torridonian. Width of section about $25 \mathrm{~km}$. Stratigraphic thicknesses according to the Geological Survey.

yielded Upper and Lower Torridonian palaeomagnetic fields fall respectively stratigraphically above and below the unconformity. This, coupled with the palaeomagnetic data presented earlier, suggests to the writer that the unconformity represents at least 50 m.y. of earth history. How does it fit in with the scheme of late Precambrian diastrophism?

\section{REFERENCES}

Crefr, K. M., 1957. The natural remanent magnetization of certain stable rocks from Great Britain. Phil. Trans. R. Soc., Lond., Ser. A, 250, 111-129.

E. IRving, and S. K. RUNCORN, 1957. Geophysical interpretation of palaeomagnetic directions from Great Britain. Phil. Trans. R. Soc., Lond., Ser. A, 250, 144-156.

Gracie, A. J., and A. D. Stewart. (In preparation.) Certain Torridonian rocks on the south side of Enard Bay, Ross-shire.

Harland, W. B., R. H. Wallis, and R. A. Gayer, 1966. A revision of the Lower Hecla Hoek succession in central north Spitsbergen and correlation elsewhere. Geol. Mag., 103, 70-97.

Irving, E., 1964. Paleomagnetism. John Wiley and Sons.

and S. K. RuNCORN, 1957. Analysis of the palaeomagnetism of the Torridonian Sandstone Series of Northwest Scotland. Phil. Trans. R. Soc., Lond., Ser. A, 250, 83-99.

LAwSON, D. E., 1965. Lithofacies and correlation within the lower Torridonian. Nature, Lond., 207, 706-708.

Runcorn, S. K., 1964. Paleomagnetic results from Pre-Cambrian sedimentary rocks in the western United States. Bull. geol. Soc. Am., 75, $687-704$. 
Williams, G. E., 1966. Palaeogeography of the Torridonian Applecross Group. Nature, Lond., 209, 1303-1306.

\section{Sedimentology Research Laboratory, UNIVERSITY OF READING. 20th May, 1966.}

\section{A. D. Stewart.}

SIR, - We are glad to have provided an occasion for Dr. Stewart's contribution, although we did not intend in our schematic table to depict time intervals, or even correlation. Our scale was intended to be concerned primarily with thicknesses, and in this connection, as well as with respect to the unconformity between lower and upper Torridonian, the left-hand column of our table should thus be revised substantially downwards.

$$
\text { W. B. Harland, R. H. Wallis, and R. A. Gayer. }
$$

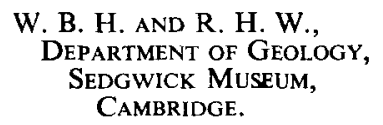

26th May, 1966.

\author{
R. A. G., \\ DEPARTMENT OF GEOLOGY, \\ UNIVERSITY COLLEGE, \\ CATHAYS PaRK, \\ CARDIFF.
}

\section{BROOD POUCHES IN THE BRACHIOPOD UNCITES : \\ A RE-INTERPRETATION}

SIR,-In 1964, in this Magazine, I interpreted the postero-lateral shelly pouches of the Devonian brachiopod Uncites as possible brood pouches. This interpretation has recently been criticized by Jux and Strauch (1966) in their comprehensive revision of this genus. In the light of this work my earlier interpretation requires modification on one important point, but does not, I believe, deserve to be abandoned altogether.

For my earlier paper I was obliged to rely on well-preserved but poorly localized specimens from early museum collections. I therefore overlooked the fact that the pouches are characteristic of all specimens of $U$. paulinae Winterfeld (cf. my Text-fig. $1 \mathrm{~A}, \mathrm{~B}$ ) which has a distinctly higher stratigraphical range than the pouchless $U$. gryphus (Schlotheim). Jux and Strauch erect a stratigraphically intermediate species, $U$. beuthi, which has rudimentary "open" pouches (cf. my Text-fig. 1C,D). There is thus a stratigraphical (and phyletic?) series, showing a gradual development of the pouches (Jux and Strauch, Abb. 17). Therefore, as Jux and Strauch tightly point out (p. 215 footnote, p. 216), my tentative suggestion that the presence or absence of pouches might be a case of sexual dimorphism must now be abandoned.

However, Jux and Strauch assume that the interpretation of the pouches as brood pouches can also be rejected. This does not follow. The suggestion of sexual dimorphism rested on the assumption that Uncites was dioecious. There is the alternative possibility that it was hermaphrodite, as a few living brachiopod species are now known to be. If it was hermaphrodite, brood pouches would be expected to be present in all adult members of the population. Jux and Strauch's observation that pouches are universal in U. paulinae accords with this interpretation. Thus the series $U$. gryphus $-U$. beuthi-U. paulinae would represent the gradual development of increasingly protected brood pouches in all members of an evolving population of hermaphrodite brachiopods. This development might have been related to the ecological differences which Jux and Strauch detect between the species concerned.

This re-interpretation is supported indirectly by the molluscan analogue I quoted in my earlier paper. Barnard (1964), while noting that the pouch of Thecalia serves as a brood pouch, also reported that he had been unable to find any shells above a length of $10 \mathrm{~mm}$. without pouches; he therefore 